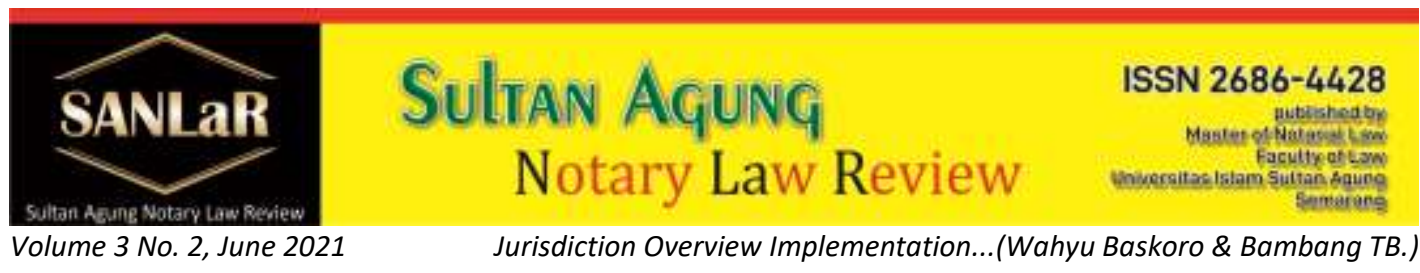

\title{
Jurisdiction Overview Implementation of Rights Transfer to Land \& Building Registration with Selling-Buying Deed
}

\author{
Wahyu Baskoro*) and Bambang Tri Bawono**) \\ ${ }^{*}$ Faculty of Law, Universitas Islam Sultan Agung (UNISSULA) Semarang, E-mail: \\ wahyubaskoro82@yahoo.co.id
$\left.{ }^{* *}\right)$ Faculty of Law, Universitas Islam Sultan Agung (UNISSULA) Semarang, E-mail: bambang@unissula.ac.id

\begin{abstract}
The purposes of this study are to: 1) Analyze the implementation of the registration of the transfer of rights to land and or buildings with a Sale and Purchase Deed at the Surakarta City Land Office. 2) Analyzing obstacles and solutions in the implementation of the registration of the transfer of rights to land and or buildings with a Sale and Purchase Deed at the Surakarta City Land Office. This research is a normative juridical approach, with descriptive analysis research specifications. Primary and secondary data collection was obtained by interview and literature study. The results of the research are: 1) The registration of the transfer of land and building rights with the Sale and Purchase Deed at the Surakarta City Land Office begins with the stage of implementing the sale and purchase transaction between the seller and the buyer. After that the sale and purchase transaction must be made a deed of sale and purchase by the PPAT, then by the PPAT it is brought to the Land Office to be registered as a certificate of ownership for the new land title holder. After the registration process, the next step is to wait for data verification from the Land Office for the issuance of certificates. 2). The obstacle in implementing the registration of the transfer of rights to land and or buildings with a Sale and Purchase Deed at the Surakarta City Land Office is that there are still many low levels of education resulting in a lack of public legal awareness, the length of the SOP for the Transfer of Name Certificates whose proof of ownership is still in the form of a Sub-district Register $C$ (Letter $C$ ), and the lack of counseling provided to the community regarding the importance of registering the transfer of land rights due to buying and selling, and land certificates. 3). The solution to overcome obstacles in implementing the registration of the transfer of land and or building rights with the Sale and Purchase Deed at the Surakarta City Land Office is to provide or publish brochures about the importance of registering the transfer of land rights due to buying and selling, conducting counseling, improving human resources through courses/training and fixing the administration of the organization.
\end{abstract}

Keywords: Deed of Sale and Purchase; Land Registration; Certificate. 


\section{Introduction}

Land has a very important role for people's lives as a place of development and also a place of community livelihood. Land is an important means of development, then in the 1945 Constitution Article 33 paragraph (3) it has been determined that "earth, water, space and natural resources contained therein are controlled by the state and used as much as possible for the prosperity of the people". Land is a very basic human need. ${ }^{1}$

The rapidly increasing demand for land, coupled with the current limited availability of land, also has a major impact on increasing the value and price of land. This increases the potential for land-related or land-related conflicts and problems to arise. The increasingly complex problems of human life caused by land today require that there be a rule that regulates the guarantee of legal certainty in the relationship between humans and land. ${ }^{2}$

In Article 2 paragraph (1) of the Basic Agrarian Law it is stated that: "Earth, water and space, including natural resources therein, are at the highest level controlled by the State as an organization of power for the entire people." the governing body will always be able to control or direct the management of the functions of the earth, water and space as well as the natural resources contained therein in accordance with existing regulations and policies, namely within the scope of juridical control with public aspects. ${ }^{3}$

One of the legal actions in transferring control of land and or building rights that is most often carried out by the community is through buying and selling. The legal act of buying and selling in the everyday sense can be interpreted as an act where someone releases money to get the desired item voluntarily. Article 1457 of the Civil Code states that buying and selling is an agreement, where one party binds himself to deliver an object and the other party pays the promised price. From the formulation of the article above, it can be concluded that the seller and buyer have their respective rights and obligations. The seller is obliged to deliver the goods sold, while the buyer is obliged to pay the price of the goods purchased to the seller. ${ }^{4}$

The act of transferring rights to land and or buildings through buying and selling must be proven by an authentic deed called a Sale and Purchase Deed (AJB)

\footnotetext{
${ }^{1}$ Bambang Eko Supriyadi, 2013, Hukum Agraria Kehutana, Raja Grafindo, Jakarta, p. 7

${ }^{2}$ Dyara Radhite Oryza Fea, 2018, Guide to Managing Home Land and Permits, Legal, Yogyakarta, p. 2

${ }^{3}$ Dyara Radhite Oryza Fea, 2018, Panduan Mengurus Tanah Rumah dan Perizinannya, Legality, Yogyakarta, p. 5

${ }^{4}$ Muhammad Bakri, 2007, Hak Menguasai Tanah Oleh Negara (Paradigma Baru Untuk Reformasi Agraria), Citra Media, Yogyakarta, p. 94
} 
made by the Land Deed Making Official (PPAT) or a Notary. The deed of sale and purchase is a document of evidence of the occurrence of a sale and purchase transaction between the seller and the buyer. The process of making AJB documents is carried out by PPAT and must be clear and paid in full. By carrying out a sale and purchase before the PPAT ${ }^{5}$, it is fulfilled the conditions of light (not a dark legal act, which is carried out secretly). The deed of sale and purchase signed by the parties proves that there has been a transfer of rights from the seller to the buyer accompanied by payment of the price. has fulfilled the cash element and shows that in real or real terms the legal act of buying and selling in question has been carried out ${ }^{6}$. The deed proves that a legal act of transferring rights has been carried out in perpetuity and payment of the price. Because the legal action taken is a legal act of transferring rights, the deed proves that the recipient of the rights (buyer) has become the new right holder. ${ }^{7}$

The city of Surakarta, also known as Solo, is an autonomous region with the status of a City under the Province of Central Java, Indonesia, with a population of 519,587 people and a density of $11,798.06 / \mathrm{km}$. Surakarta is a developed city because of many developments. A lot of development creates a lot of need for land. Most of the land and/or buildings owned by the community are land owned by sale and purchase. In order to obtain legal certainty and strengthen evidence regarding the ownership of the sale and purchase, the community registers it at the local Land Office. Based on the background of the problem above, the writer is interested in analyzing the thesis problem with the title "Juridical Review of the Implementation of the Registration of Transfer of Land and Building Rights with the Sale and Purchase Deed at the Surakarta City Land Office ${ }^{8}$.

\section{Research Methods}

The approach method used in this research is empirical juridical. Juridical empirical namely research that focuses on individual or community behavior in relation to the law. ${ }^{9}$ The specification of the research used is descriptive

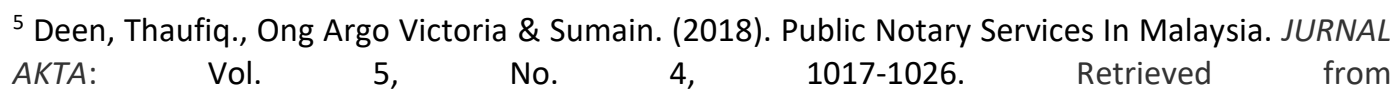
http://jurnal.unissula.ac.id/index.php/akta/article/view/4135

${ }^{6}$ Winarti, \& Ngadino. (2019). Review Of Juridical Registration Implementation And Transfer Of Land Or Building With Deed Land Sale In The Office Of The Samarinda City. JURNAL AKTA: Vol. 6, No. 4, 711-718. Retrieved from http://jurnal.unissula.ac.id/index.php/akta/article/view/7595

${ }^{7}$ Adrian Sutedi, 2018, Peralihan Hak Atas Tanah dan pendaftarannya, ed.9, Sinar Grafika, Jakarta, p. 77

${ }^{8}$ Farhati, Dewi \& Akhmad Khisni. (2018). Legal Review Of Implementation Endowments Authority Relating To The Under Hand Agreement Made By Waqif (Case Study In Kua Wonosalam, Demak). JURNAL AKTA: Vol. 5, No. 3. Retrieved from http://jurnal.unissula.ac.id/index.php/akta/article/view/3256/2392

${ }^{9}$ Soerjono Soekanto dan Sri Mamadji, 2009, Penelitian Hukum Normatif: Suatu Tinjauan Singkat, Raja Grafindo Persada, Jakarta, p.1 
analytical. Primary data collection was done by interview method. The type of interview used in this study using guided free interviews, is a combination of free and guided interviews. ${ }^{10}$ Secondary data is data obtained from the results of a literature review or a review of various literatures or library materials related to research problems or materials which are often called legal materials. ${ }^{11}$ Analysis of the data used in this study is a qualitative analysis.

\section{Results and Discussion}

\subsection{Implementation of the registration of the transfer of land and building rights with the Sale and Purchase Deed at the Surakarta City Land Office}

In order to guarantee certainty of rights and legal certainty over land, the UUPA has outlined the necessity to carry out land registration throughout Indonesia. With the holding of land registration, the disputing parties can easily find out the legal status or position of the land they are dealing with, their location, area, and boundaries, who owns it and what charges are on it. As mandated by Article 19 of the UUPA. The article includes the general provisions of land registration in Indonesia, namely: ${ }^{12}$

1. To ensure legal certainty by the government, land registration is held throughout the territory of the Republic of Indonesia according to the provisions stipulated in a Government Regulation.

2. The registration referred to in paragraph 1 of this article includes:

a. Measurement, mapping and bookkeeping of land.

b. Registration of land rights and the transfer of these rights

c. Provision of letters of proof of rights, which serve as strong evidence.

3. Land registration is carried out taking into account the state and community conditions, the needs of socio-economic traffic and the possibility of its implementation, according to the consideration of the Minister of Agrarian Affairs

In the city of Surakarta, in order to make it easier to carry out legal actions related to land rights which become the object of transferring to the recipient of the right, then the transfer of rights must be carried out before the Land Deed Making Officer (PPAT) who makes the deed and is registered at the Surakarta City Land Office by the owner of the property right. or by the right holder

\footnotetext{
${ }^{10}$ lbid , p. 84

${ }^{11}$ Mukti Fajar dan Yulianto, 2010, Dualisme Penelitian Hukum Normatif dan Empiris, Pustaka Pelajar, Yogyakarta, p. 156

${ }^{12}$ Article 19 paragraph (1) UUPA
} 
concerned. When facing PPAT to make a Deed of Sale and Purchase of land, the conditions that must be met include the following:

1. The conditions prepared by the seller include:

a. Original Certificate of Land Rights to be sold.

b. Identity Card (KTP).

c. Family Card (KK)

d. Proof of Payment of Land and Building Tax (PBB)

e. Letter of approval from the family

f. A statement that the land to be sold is not in dispute.

2. The terms prepared by the buyer include:

a. Identity Card (KTP).

b. Family Card (KK).

c. Money for payments that can be made in cash before the PPAT.

If all of these conditions have been met, then the seller and buyer must submit these requirements to PPAT and then PPAT will process the sale and purchase transaction of land rights by making a Sale and Purchase Deed (AJB) between the seller and the buyer. Then the deed that has been signed by the parties who made the agreement on the transfer of land rights and the witnesses who were present in the process of transferring the land rights, then by the PPAT it is brought to the Land Office to be registered as a certificate of ownership for the new land rights holder ${ }^{13}$.

For further details implementation the registration of the transfer of rights to land and buildings with a deed of sale and purchase at the Surakarta City Land Office is:

\section{Transfer of Rights Registration}

Registration of transfer of land rights by way of buying and selling at the Surakarta City Land Office, the applicant does not come directly to the Land Office. However, the registration of the transfer of rights is represented by PPAT. This is because in addition to PPAT's duty to make a deed of sale and purchase of land, PPAT is also in charge of registering the transfer of rights at the local land office which is no later than 7 days from the signing of the deed of sale and purchase of land rights. Before making the transfer of ownership rights to land by way of buying and selling, the PPAT concerned is obliged to conduct an examination of the authenticity of the certificate to the Land Office.

\footnotetext{
${ }^{13}$ Rachmawati, Noor., \& Hanim, Lathifah. (2018). Notary Role in The Establishment of Foreign Investment Limited Company Based on The Act No. 25 Of 2007 on Investment in Semarang. JURNAL AKTA: Vol. 5, No. 4, 965-974. Retrieved from http://jurnal.unissula.ac.id/index.php/akta/article/view/3939
} 
The Land Deed Making Official is obliged to submit the PPAT deed and other documents needed for the registration of the transfer of land rights in question to the local land office, no later than seven working days from the signing of the deed in question. The documents submitted by PPAT in the context of registering the transfer of land rights or ownership rights to the apartment unit to the local land office are:

a. A letter of application for registration of the transfer of rights signed by the recipient of the rights (buyer) or his proxies,

b. A written power of attorney from the right recipient (buyer) if the applicant for registration of the transfer of rights is not the right recipient (buyer).

c. Deed of sale and purchase by PPAT who at the time of making the deed was still in office and whose working area included the location of the land in question

d. Proof of identity of the transferor (the seller)

e. Proof of identity of the party receiving the rights (buyer)

f. Certificate of original land rights transferred (for sale)

g. Permit to transfer rights if needed

h. Proof of payment of payment of land and building rights acquisition fees (BPHTB), in the event that the duty is payable, and

i. Proof of payment of income tax (PPh), in the event that the tax is payable.

After the registration process, the next step is to wait for data verification from the Land Office for the issuance of certificates.

2. Certificate Submission

Certificate of land rights whose holder's name has been changed from the holder of the right to land long as the seller becomes the new right holder as the buyer by the head of the local district/city land office, then it is submitted to the applicant for registration of the transfer of land rights through the buyer or his proxies. According to the Basic Agrarian Law, registration is a strong proof of the validity of buying and selling carried out, especially in relation to third parties with good intentions. Registration administration is open so that everyone is considered to know it. ${ }^{14}$

According to the Basic Agrarian Law, registration is a strong proof of the validity of buying and selling carried out, especially in relation to third parties with good intentions. Registration administration is open so that everyone is considered to know it. ${ }^{15}$ Article 19 of the Basic Agrarian Law regulates land registration.

\footnotetext{
${ }^{14}$ A. P. Parlindungan, 1990, Pendaftaran Tanah di Indonesia, Mandar Maju, Bandung, p. 14.

15 Ibid, p.15.
} 
As an implementation of Article 19 of the Basic Agrarian Law regarding land registration, Government Regulation Number 24 of 1997 concerning Land Registration was issued. Registered means recorded and issued proof of rights. The proof of rights is called a land title certificate which consists of a copy of the land book and a measuring document which is bound together in one cover. The certificate is a strong means of proof, meaning that the information contained in it has legal force and must be accepted as true information, as long as and as long as there is no other means of proof that proves otherwise.

The implementation of this land registration is one way to obtain a certificate for legal certainty on the land and or buildings it owns. This is in line with the theory of legal certainty which normatively is when a regulation is made and promulgated with certainty because it can provide clear and logical arrangements. It is clear in the sense that it does not cause doubt or multiple interpretations, and logical in the sense that the law becomes a system of norms with other norms so that it does not clash or cause conflicting norms or the existence of ambiguity and void of norms. Elucidation of Article 6 letter $i$ of the Law of the Republic of Indonesia Number 12 of 2011 concerning the Establishment of Legislation, State Gazette of the Republic of Indonesia of 2011 Number 82, Supplement to the State Gazette of the Republic of Indonesia Number 5234, stipulates that in making laws and regulations, one of them must reflect the principle of legal certainty. In addition to providing legal certainty, the implementation of the transfer of land rights with a deed of sale and purchase at the Land Office is able to provide legal protection and justice for the community.

3.2. Obstacles and solutions in the implementation of the registration of the transfer of rights to land and or buildings with a Sale and Purchase Deed at the Surakarta City Land Office

Any transfer of ownership rights to land must be registered at the local land office. The registration of the transfer or transfer of rights is intended so that third parties know that the sale and purchase of the land has been carried out. Because if the sale and purchase of land is not registered and the plot of land is not actually controlled by the new owner, this opens up opportunities for those with bad intentions to resell the land to other parties. By registering the land, you will get a Certificate of Land Ownership which is called a certificate. The granting of the certificate is intended to give authority to those who have the 
right to use the land. Registration is carried out because by registering the status of ownership of land it becomes clear and can be used as a strong evidence. ${ }^{16}$

Departing from one of the problems above, in the implementation of the registration of the transfer of rights to land and or buildings with the Sale and Purchase Deed at the Surakarta City Land Office, it does not always run smoothly. There are several factors that often hinder it, including:

1. Barriers arising from society

a. There are still many low levels of education, resulting in a lack of legal awareness of the community, where people assume that by having a certificate in the name of another person (the seller), the land owner has obtained land rights and guarantees legal certainty.

b. People feel reluctant to take care of the transfer of land rights due to the costs which they think are quite high and will only take up their time.

2. Barriers arising from the Land Office

a. The duration of the SOP (Standard Operating Procedure) for the process of transferring the name of a certificate whose proof of ownership is still in the form of a Sub-district Register $\mathrm{C}$ (Letter $\mathrm{C}$ ). For example, in the case of buying and selling land, it turns out that the land does not yet have a Land Title Certificate, and the proof of ownership is still in the form of a Register $\mathrm{C}$ from the village (Letter $\mathrm{C}$ ). To be able to carry out the process of buying and selling land, it really takes a long time, because the seller must first convert from the Village Register C (Letter C) which is converted into a Land Rights Certificate. Based on the SOP (Standard Operating Procedure) that the conversion takes approximately 3 months at the fastest and 6 months at the longest.

b. Lack of counseling given to the community regarding the importance of registering the transfer of land rights due to buying and selling, and land certificates.

c. Lack of document storage space, so many documents are not organized and sometimes there are lost documents

One of the legal acts of transferring ownership rights to land is by buying and selling land. In the current practice of buying and selling land, it is hoped that there will be legal certainty that can guarantee the continuity of these activities through the transfer of the name of the certificate of land rights. The transfer of

\footnotetext{
${ }^{16}$ Erfa Meiyani, 2009,Pelaksanaan Pendaftaran Peralihan Hak Milik Atas Tanah Dengan Cara Jual Beli Di Kantor Pertanahan Kabupaten Kudus, Faculty of Social, Universitas Negeri Semarang, p.3
} 
title to land rights certificates carried out by way of buying and selling is another legal act of transferring rights, except that the transfer of rights through auction can only be registered if it is proven by a deed made by the authorized PPAT. Thus, it means that any transfer of ownership rights to land, which is carried out in the form of buying and selling, exchanging or grants must be made before the PPAT. ${ }^{17}$

Before the PPAT makes the transfer of land rights, especially the transfer of ownership rights by way of buying and selling which is carried out by making a deed of sale and purchase, then the PPAT concerned is obliged to check / check the certificate at the local land office by showing the original certificate. According to article 103 paragraph (1) of the Regulation of the Minister of State for Agrarian Affairs/Head of the National Land Agency Number 3 of 1997, it is explained that PPAT is obliged to submit the PPAT deed and other documents required for the registration of the transfer of the right in question to the Land Office, no later than 7 (seven) working days from the signing of the deed in question.

The steps of the Surakarta City Land Office in overcoming obstacles to the process of transferring land rights through buying and selling are:

1. Steps in dealing with obstacles caused by the community, among others:

a. Provide or publish brochures about the importance of registering the transfer of land rights due to buying and selling. This step is done by giving the brochures to the community and sticking the brochures on the bulletin board at the Village Head's Office.

b. The Land Office cooperates with the Village Head to conduct counseling on land issues as an effort to raise public awareness about the importance of certificates.

2. Steps in dealing with obstacles caused by the Land Office, among others:

a. By fixing the performance of the Surakarta City Land Office, fixing the apparatus from within, namely the officers who handle the problem of registration of transfers and certificates of land rights, through courses/training.

b. The Surakarta City Land Office is trying to fix the administration because it is the organization of human resources.

The registration of the transfer or transfer of rights is intended so that third parties know that the sale and purchase of the land has been carried out.

${ }^{17}$ Wantjik Saleh, 1982, Hak Anda Atas Tanah, Ghalia, Jakarta, p.30 
Because if the sale and purchase of land is not registered and the plot of land is not actually controlled by the new owner, this opens up opportunities for those with bad intentions to resell the land to other parties.

In buying and selling, the most important thing is the interests of the buyer in relation to the seller. The land rights in question have been transferred to the buyer when the legal act of buying and selling has been completed before the Land Deed Making Official (PPAT). For this reason, the PPAT deed is proof that the buyer has become the new right holder. The interests of third parties are not always involved in the transfer of rights, therefore the registration of the transfer of rights serves to strengthen the position of the buyer in relation to third parties, whose interests may be involved and are not a condition for the transfer of the rights concerned to him.

\section{Closing}

The registration of the transfer of land and building rights with the Sale and Purchase Deed at the Surakarta City Land Office begins with the stage of implementing the sale and purchase transaction between the seller and the buyer. After that, the sale and purchase transaction must be made by the PPAT. PPAT will check the Deposit Receipt (STTS) and PBB Tax Return (SPPT). This check is carried out to ensure that there are no arrears in PBB payments. At the same time to calculate the costs and taxes that are the obligations of each party. Where the calculation of these costs can be done based on the Sales Value of the Tax Object (NJOP). Then the deed that has been signed by the parties who made the agreement on the transfer of rights to the land and the witnesses who were present in the process of transferring the rights to the land. After the registration process, the next step is to wait for data verification from the Land Office for the issuance of certificates. And the obstacles in implementing the registration of the transfer of rights to land and or buildings with the Sale and Purchase Deed at the Surakarta City Land Office are 1). Barriers arising from society: a). There are still many low levels of education resulting in a lack of public legal awareness, b). Communities feel reluctant to take care of the transfer of land rights due to the costs which they think are quite high and will only take up their time. 2). Barriers arising from the Land Office: a). Length of SOP (Standard Operational Procedure) Process for Transferring Names of Certificates whose Proof of Ownership is Still in the form of a Registered Letter $C$ to village, b). Lack of counseling given to the community regarding the importance of registering the transfer of land rights due to buying and selling, and land certificates. c). Lack of storage space for documents, so that many documents are not organized and sometimes there are lost documents. The solution to overcome obstacles in the implementation of the registration of the transfer of rights to land and or buildings with a Sale and Purchase Deed at the Surakarta City Land Office is to provide or publish 
brochures about the importance of registering the transfer of land rights due to buying and selling, conducting counseling on land issues as an effort to raise awareness the community regarding the importance of certificates, fixing the performance of the Surakarta City Land Office, fixing the apparatus from within, namely officers who handle the problem of registration of transfers and certificates of land rights, through courses/training and fixing the administration because it is as an organization of human resources.

\section{References}

Journals:

[1] Fredrik Mayore, Peralihan Hak Atas Tanah Melalui Jual Beli Menurut Peraturan Pemerintah Nomor 24 Tahun 1997, Jurnal Lex Crimen Vol. VI/No. 1/Jan-Feb/2017

[2] Winarti, \& Ngadino. (2019). Review Of Juridical Registration Implementation And Transfer Of Land Or Building With Deed Land Sale In The Office Of The Samarinda City. JURNAL AKTA: Vol. 6, No. 4, 711-718. Retrieved

from http://jurnal.unissula.ac.id/index.php/akta/article/view/7595

[3] Deen, Thaufiq., Ong Argo Victoria \& Sumain. (2018). Public Notary Services In Malaysia. JURNAL AKTA: Vol. 5, No. 4, 1017-1026. Retrieved from http://jurnal.unissula.ac.id/index.php/akta/article/view/4135

[4] Farhati, Dewi \& Akhmad Khisni. (2018). Legal Review Of Implementation Endowments Authority Relating To The Under Hand Agreement Made By Waqif (Case Study In Kua Wonosalam, Demak). JURNAL AKTA: Vol. 5, No. 3. Retrieved from http://jurnal.unissula.ac.id/index.php/akta/article/view/3256/2392

[5] Harjanto, Fery., \& Gunarto. (2018). Effects Of Creation Deed of Sale and Purchase of Land Which Does Not Match Procedure of Making Land Deeds. JURNAL AKTA: Vol. 5, No. 4, 857-864. Retrieved from http://jurnal.unissula.ac.id/index.php/akta/article/view/3718

[6] Rachmawati, Noor., \& Hanim, Lathifah. (2018). Notary Role in The Establishment of Foreign Investment Limited Company Based on The Act No. 25 Of 2007 on Investment in Semarang. JURNAL AKTA: Vol. 5, No. 4, 965-974. http://jurnal.unissula.ac.id/index.php/akta/article/view/3939

Books: 
[1] Adrian Sutedi, 2018, Peralihan Hak Atas Tanah dan pendaftarannya, cet.9, Sinar Grafika, Jakarta

[2] Bambang Eko Supriyadi, 2013, Hukum Agraria Kehutana, Raja Grafindo, Jakarta

[3] Dyara Radhite Oryza Fea, 2018, Panduan Mengurus Tanah Rumah dan Perizinannya, Legality, Yogyakarta

[4] Era Meiyani, 2009, Pelaksanaan Pendaftaran Peralihan Hak Milik Atas Tanah Dengan Cara Jual Beli Di Kantor Pertanahan Kabupaten Kudus, Skripsi Fakultas Hukum, Universitas Negeri Semarang

[5] Erfa Meiyani, 2009,Pelaksanaan Pendaftaran Peralihan Hak Milik Atas Tanah Dengan Cara Jual Beli Di Kantor Pertanahan Kabupaten Kudus, Faculty of Social Universitas Negeri Semarang

[6] Maria SW, Sumardjono (V), 22 July 1993, Aspek Teoritis Peralihan Hak Atas Tanah, makalah seminar"Peralihan Hak-Hak Atas Tanah, Aspek Hukum dan Segi Praktek yang Aktual Dewasa ini”, Jakarta, Yayasan Biluta dan Kantor Chandra Motik Djemat \& Associates.

[7] Muhammad Bakri, 2007, Hak Menguasai Tanah Oleh Negara (Paradigma Baru Untuk Reformasi Agraria), Citra Media, Yogyakarta

[8] Mukti Fajar dan Yulianto, 2010, Dualisme Penelitian Hukum Normatif dan Empiris, Pustaka Pelajar, Yogyakarta

[9] P. Parlindungan, 1990, Pendaftaran Tanah di Indonesia, Mandar Maju, Bandung

[10] Rencana Program Investasi Jangka Menengah (RPIJM) Kota Surakarta 20162020

[11] Sabrina Ayu, 2015, Pelaksanaan Balik Nama Sertifikat Hak Milik Dalam Jual Beli Tanah, Naskah Publikasi Skripsi, Universitas Muhammadiyah Surakarta

[12] Soedharyo Soimin, 2004, Status Hak dan Pembebasan Tanah, cet. 1, Sinar Grafika, Jakarta

[13] Soerjono Soekanto dan Sri Mamadji, 2009, Penelitian Hukum Normatif: Suatu Tinjauan Singkat, Raja Grafindo Persada, Jakarta

[14] Sudikno Mertokusumo, 2009, Penemuan Hukum, Citra Aditya Bakti, Bandung

[15] Supriadi, 2010, Hukum Agraria, Cetakan Keempat, Sinar Grafika, Jakarta

[16] Wantjik Saleh, 1982, Hak Anda Atas Tanah, Ghalia, Jakarta 